\title{
OSP-IMMUNOFLUORESCENT REMYELINATING OLIGODENDROCYTES IN THE BRAINSTEM OF TOXICALLY-DEMYELINATED WISTAR RATS
}

\author{
Eliza Simone Viégas Sallis', Cinthia Melazzo Mazzanti ${ }^{2}$, Alexandre Mazzanti', \\ Luis Antonio Violin Pereira ${ }^{3}$, Kélen Fabíola Arroteia ${ }^{3}$, Rafael Fustigatto \\ Charles Pelizzari', Aline Rodrigues' ${ }^{1}$ Dominguita Lühers Graça ${ }^{1}$
}

\begin{abstract}
Central nervous system (CNS) remyelination following toxically-induced demyelination is a well known process. Oligodendrocytes constitute the bulk of the myelinating cells in the brain where as Schwann cells overwhelm oligodendrocytes numbers in spinal cord remyelination. Despite the common knowledge of these facts, we still do not know completely the origin of both remyelinating cells. The present study investigated the participation of mature oligodendrocytes in remyelination after ethidium-bromide (EB) induced demyelination in the brainstem of normal and cyclosporin A-immunosuppressed Wistar rats. Thirty adult female rats were divided into three experimental groups. In group 1 the rats received a single intracisternal injection of $10 \mu \mathrm{L}$ of $0.1 \%$ ethidium bromide $(E B)$ in $0.9 \%$ saline $(n=10)$; in group 2 the rats received the $E B$ injection while immunosuppressed with cyclosporin $A(n=10)$; in group 3 the rats received a single $10 \mu \mathrm{L}$ injection of $0.9 \%$ saline while treated with cyclosporin $A$. The rats were killed at 15, 21 and 31 days after injection. Within the EB lesions, from 15 days onward many cells within the periphe ry of the lesions stained positive for OSP (oligodendrocyte specific protein) a marker for mature oligodend rœytes and myelin. This cell marking signals that, at least, part of the process of repairing the myelin sheaths is carried out by mature cells of the oligodendrocyte lineage.
\end{abstract}

KEY WORDS: toxic demyelination, remyelination, oligodendrocytes, oligodendrocyte specific protein (OSP), ethidium bromide.

\section{Oligodendrócitos remielinizantes positivos para OSP - proteína específica do oligodendrócito- no tronco encefálico de ratos Wistar desmielinizados toxicamente}

\begin{abstract}
RESUMO - A remielinização do sistema nervoso central após desmielinização tóxica é um processo bem conhecido. No encéfalo, os oligodendrócitos remielinizam uma área maior do que na medula espinhal, onde as células de Schwann são preponderantes. Embora esses fatos sejam bem conhecidos, ainda não se conhece com certeza a origem das células remielinizantes. Esta investigação foi desenhada para esclarecer a participação de oligodendrócitos maduros na re const rução das bainhas perdidas após a desmielinização induzida por brometo de etídio (BE) no tronco encefálico de ratos Wistar normais e imunossuprimidos com ciclosporina A. Trinta ratos fêmeas adultas foram divididos em três grupos experimentais. No g rupo 1, os ratos receberam uma injeção de $10 \mu \mathrm{L}$ de BE em 0,9\% salina $(n=10)$ na cisterna basal; no grupo 2 , os ratos receberam a injeção de $B E$ e foram tratados com ciclosporina $A(n=10)$; no grupo 3 os ratos receberam uma injeção de $10 \mu \mathrm{L}$ de $0,9 \%$ salina e foram tratados com ciclosporina $A$. Os ratos foram sacrificados aos 15, 21 e 31 dias após a injeção. A partir dos 15 dias muitas células da periferia das lesões tiveram ma rcação positiva para OSP (proteína específica do oligodendrócito), marcador de oligodendrócitos maduros e mielina. Assim, foi possível comprovar que células maduras da linhagem oligodendroglial participam do processo de remielinização neste modelo gliotóxico.
\end{abstract}

PALAVRAS-CHAVE: desmielinização tóxica, remielinização, oligodendrócitos, proteína específica do oligodendrócito (OSP), brometo de etídio.

\footnotetext{
1PPPGMV da Universidade Federal de Santa Maria RS, Brazil; ${ }^{2}$ PPGBQ da Universidade Federal do Rio Grande do Sul, Brazil; ${ }^{3}$ Departamento de Histologia e Embriologia da Universidade Estadual de Campinas (UNICAMP) SP, Brazil; ${ }^{4}$ Curso de Graduação em Medicina Veterinária da Universidade Federal de Santa Maria RS, Brazil.
}

Received 18 August 2005, received in final form 28 November 2005. Accepted 23 January 2006.

Dra. Dominguita L. Graça - Departamento de Patologia UFSM - 97105-900 Santa Maria RS - Brasil. E-mail: dlgraca@smail.ufsm.br 
Oligodendroytes are the myelin-producing cells of the central nervous system (CNS). They occur in both the gray matter- as satellites for neurons- and the white matter- as interfascicular cells. Yet, satellite cells have the potentiality to form myelin'. Demyelination (loss of myelin of intact axons) due to local injection of gliotoxic agents proved to be useful to study the pathogenesis of remyelination ${ }^{2}$. Among those agents, the fluorescent dye ethidium bormide (EB) has been used to induce demyelination in Wistar rats within the spinal $\operatorname{cord}^{3,4}$, within the brain $^{5,6}$ and, within the sciatic nerve ${ }^{7}$. In the CNS remyelination was carried out by oligodendrocytes and Schwann cells ${ }^{3}$.

Due to the presence of lymphocytes within the lesions, Bondan et al. ${ }^{6,8}$ investigated the response of immunosuppressed Wistar rats to a local injection of $E B$ in the pons. The rats treated with either cyclophosphamide or cyclosporin A showed partial remyelina tion by oligodendroytes and occasional Schwann cells intermingled with cystic cavities. At the time of the investigation, the origin of the remyelinating oligodendrocytes was not known.

It was the aim of this study to find out if the remyelinating cells were mature or immature oligodendrocytes by marking the cells with OSP ${ }^{9}$. OSP (oligodendrocyte-specific protein) is a transmembrane protein, the third most abundant CNS myelin protein contributing to $7 \%$ of the total myelin protein ${ }^{10}$, and expressed in mature reactive cells and myelin.

\section{METHOD}

Thirty female Wistar rats $(250-300 \mathrm{~g})$ were used. The rats were divided into three groups and all had an intracisternal injection of either EB or $0.9 \%$ saline as follows. In group 1 the rats received $10 \mu \mathrm{L}$ of $0.1 \% \mathrm{~EB}$ in $0.9 \%$ saline in the basal cisterna; in group 2, the rats received the $E B$ injection and were immunosuppressed with cyclosporin-A; in group 3 , the rats received $10 \mu \mathrm{L}$ of $0.9 \%$ saline while immunosuppressed with cyclosporin A.

The rats were anesthetized with ketamin and xylazine $(5: 1 ; 0.1 \mathrm{ml} / 100 \mathrm{~g})$ and a burr-hole was made on the right side of the skull, $0.8 \mathrm{~cm}$ rostral to the fronto-parietal suture. The injections were made according to Pereira et al. ${ }^{5}$, with a hand-held Hamilton syringe through the burr hole in a vertical position and the contents freed when the needle reached the base of the skull, into the basal surface of the pons. The skin was sutured and the rats allowed to recover. The rats from group 2 were injected cyclosporin A (San$\operatorname{dimun}^{\circledR}$ ) intraperitoneally, $10 \mathrm{mg} / \mathrm{Kg}$ on a daily basis for seven days and subsequently three times a week with a 48 $h$ interval. The first cyclosporin A injection was made soon after surgery. The rats were maintained in collective cages (3-5 rats) and fed ration and water ad libitum.

For each group the rats were perfused under deep anes- thesia with $10 \%$ buff e red formaline via the left ventricle at 15 (3) 21 (4) and 31 days (3) after injection (a.i). Brainstem coronal slices with the lesion were separated into two matching portions: one was immersed in TissueTek ${ }^{\circledR}$ and frozen at $-80^{\circ} \mathrm{C}$, the other half was embedded in paraffin for ro utine processing.

For the immunofluorescence studies, 8 to $12 \mu \mathrm{m}$ frozen sections were obtained in cryostat and allowed to dry for $1 \mathrm{~h}$ at room temperature (RT) before the immunoreaction. Selected sections were post-fixed with methanol for 2 minutes at $-20^{\circ} \mathrm{C}$ and allowed to dry. To blocking non-specific sites, the sections were incubated with $0.05 \mathrm{M}$ tris-buffersaline (TBS) $\mathrm{pH} 7.4$ added with $1 \%$ bovine serum albumin (BSA) for 30 minutes at room temperature and washed with sequential incubations with $0.05 \mathrm{M}$ TBS. To make membranes permeable, the sections were incubated with $0.05 \mathrm{M}$ TBS added with $1 \%$ BSA and $0.1 \%$ of triton-X for 30 minutes at room temperature and washed with $0.05 \mathrm{M}$ TBS. The sections were then incubated with anti-OSP primary antibody diluted 1:100 in 0.05 M TBS with 1\% BSA and 0.01\% triton$X$, overnight at $4^{\circ} \mathrm{C}$. After washing with $0.05 \mathrm{M}$ TBS, the sections were incubated with fluorescein conjugated (FITC) anti-rabbit secondary antibody diluted 1:100 in 0.05M TBS for 60 minutes at room temperature and protected fro $\mathrm{m}$ light. The sections were washed with $0.05 \mathrm{M}$ TBS and mounted in fluorescent medium (Vectashild). Glass coverslips were walled with enamel. Fluorescence of the slides was observed with a Nikon fluorescence photomicroscope and the images were processed in the Image software Adobe Photoshop.

Paraffin embedded tissues were trimmed at $6 \mu \mathrm{m}$, dehydrated with increased concentrations of ethan ol, stained with hematoxylin and eosin (H\&E) and Weill staining, mounted in Entellan ${ }^{\odot}$ with glass coverslips and studied and photographed under an Olympus BX41 light microscope.

\section{RESULTS}

EB induces a demyelinating lesion following destruction of glial cells as previously demonstrated by our grou $\mathrm{p}^{3-6}$. Naked axons undergo remyelination by oligodendrocytes and occasional Schwann cells. Within the brain, most of remyelination is carried out by oligodendrocytes that are firstly recognized in the lesions around day 13 after EB injection ${ }^{6}$.

In the H\&E-stained lesions of this investigation, many round nuclei cells, interpreted as glial cells, slender cell processes and abundant gitter cells were found at 15 days a.i. (Fig $1 \mathrm{~A}$ ). Weill staining emphasized new myelin being produced as the lesions developed (Fig 1B).

In normal Wistar rats as well as cyclosporine Aimmunosuppressed Wistar rats, remyelination was well advanced at 21 days after EB injection in groups 1 and 2. Many cells related to axons and thin new sheaths could be seen. From 15 days onward OSP-immunoflu rescent oligodendrocytes were conspicuous within the lesions. A strong immunoflourescence mar- 


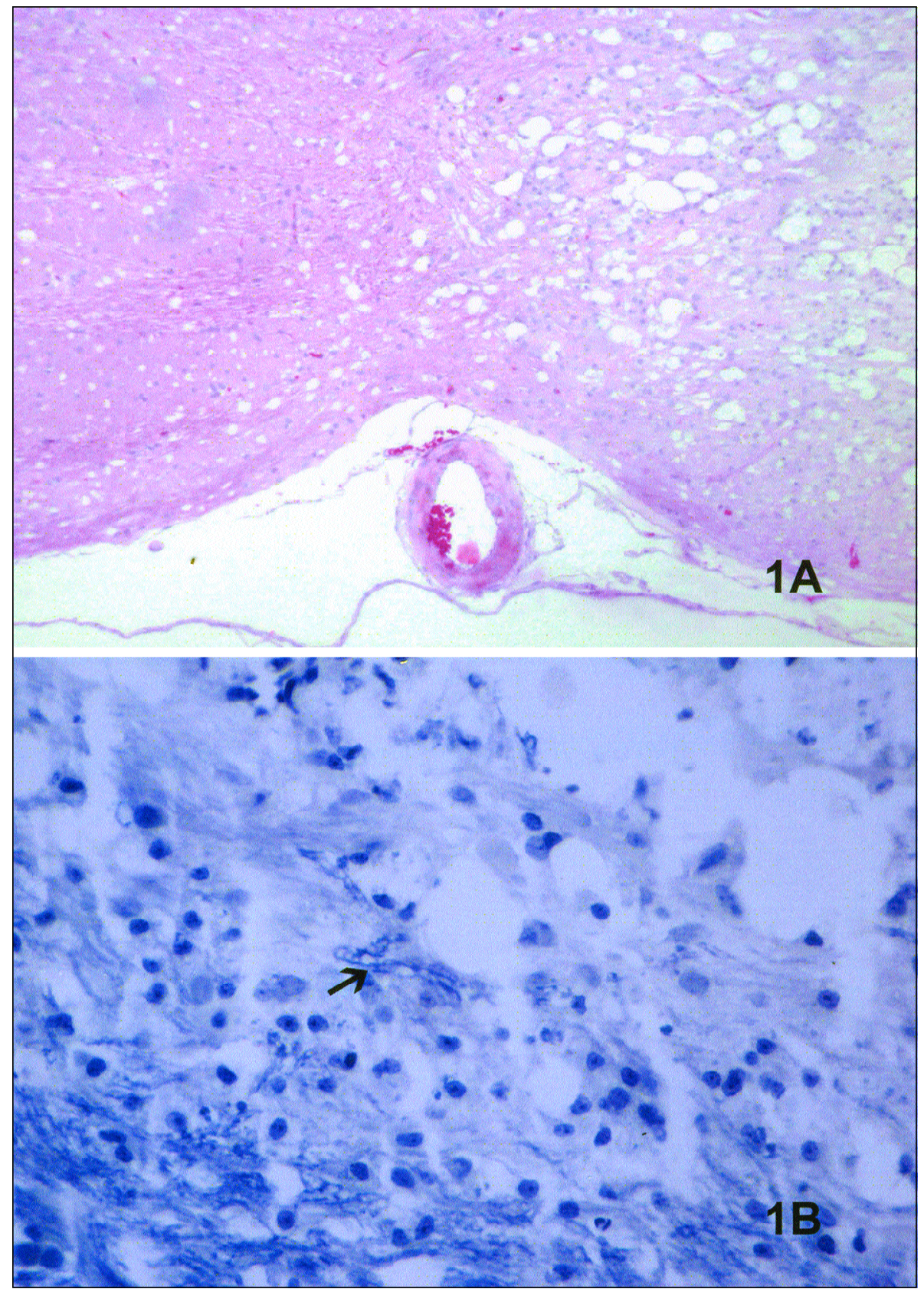

Fig 1. 21 days lesion from a group 2 rat within the pons. A. Many round-nuclei glial cells are observed in this rather compact demyelinat ed lesion. H\&E, 100X: B. New thin myelin sheaths (arrow) stain posi tive round the periphery of the lesion. Weil, 200X. ked broadly branched cells (Fig 2) that extended processes in an expanded extracelullar space where repair of myelin sheaths was under way. Immunofluorescent protein localized primarily within the outer membranes and appeared as concentrated both on the cell body as on the processes.

At all times in sections from groups 1 and 2, some round cells with eosinophilic dense cytoplasm within the tissue, interpreted as immature oligodendrocytes in EM studies ${ }^{8}$ did not mark positive for OSP. Both, mature and immature cells in normal as in immunosuppressed rats, lied in areas where astrocytic processes were conspicuous.
The lesions induced by the saline injection in group 3 consisted on a mild traumatic lesion along the needle track that induced astrocytic isomorphic gliosis.

\section{DISCUSSION}

CNS demyelination induced by EB is followed by remyelination by oligodendrocytes and Schwann cells. The area of Schwann cell remyelinated sheaths is larger in the spinal cord than in the brain due to regional diffe rences in numbers of astrocytes within the CNS ${ }^{11}$. The early disappearance of astrocytes and the glial limiting membrane after EB injection allows Schwann cells 


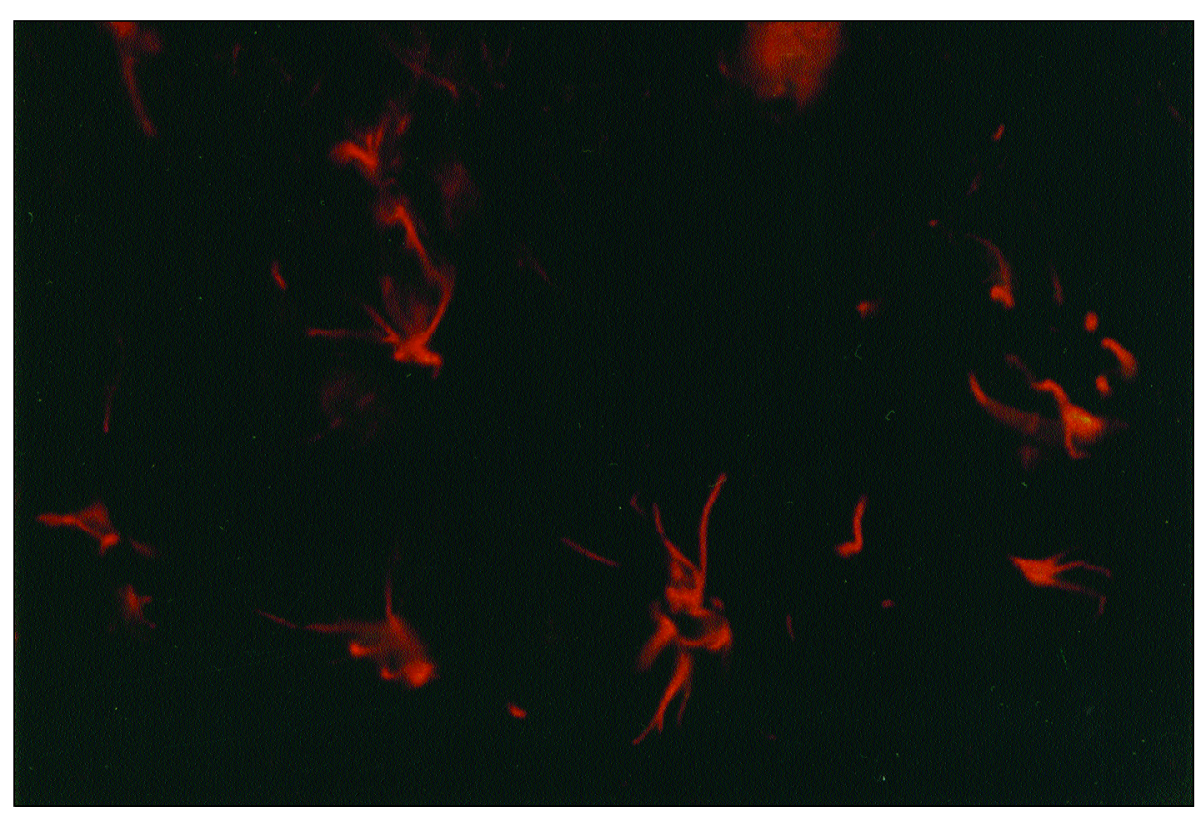

Fig 2. Large broadly branched OSPimmunofluorescent oligodendro cytes from the periphery of the lesion in Fig 1, 400X. to invade the CNS in order to remake the lost sheaths after myelinating cells commit to the naked axons ${ }^{12,13}$. Once oligodendrocytes become the main myelin repairing cells within the brain, it was relevant to find out if they are either mature or immature considering the postmitotic nature of these cells.

In EB-induced lesions in the brainstem of norm a I Wistar rats oligodendrocytes remyelinate over the narrow area lining the normal tissue ${ }^{5}$, suggesting that mature cells with a functional reserve rebuild the sheaths. After EB injection in cylosporin A-immunosuppressed Wistar rats, many round oligodendrocytes with large amounts of rough endoplasmic reticulum approach the naked axons. These cells are very suggestive of immature oligodendrocytes ${ }^{8}$, which could be derived from a common progenitor that gives rise to astrocytes and oligodendrocytes ${ }^{14}$. Confirmation of their condition of newly differentiated cells of the lineage will be provided by NG2 labelling ${ }^{15}$.

The fact that some oligodendrocytes label positive for fluorescent OSP signals to the formation of tight junctions between adjacent myelin lamellae made by quiescent nonproliferating and nonmigratory mature reactive cells from the area ${ }^{16}$, which constitute a source to remyelinate the demyelinated axons as previously suggested ${ }^{17}$. It is proposed that these mature cells initiate remyelination while newly differentiated cells reach the status to proceed the repair of the lost sheaths.

Both cells, mature and immature, and in normal and immunosuppressed animals, lie in areas where as troytic processes are conspicuous, confirming the need of astrocytes as the third element of the CNS for a stable relationship between axons and oligodendrocytes $^{13}$.

In chronically demyelinated lesions as those of multiple sclerosis, the lack of remyelination may be ascribed more to the unchecked chronic immune reaction and less to the glial scar that does not completely hinder myelinating cells migration toward the myelin-demanding naked axons ${ }^{18}$. The discovery of progenitor oligodendrocytes within the adult brain even within multiple sclerosis lesions ${ }^{19}$, brought in some hope although the complex molecular environment in which remyelination takes place remains largely unknown. Molecular biology techniques may be of great help to find out which factors concerning remyelination are dysregulated in either chronically or recurrently demyelinated lesions ${ }^{20}$.

Acknowledgements - The authors appreciate the technical assistance of Maria Andreia Inkelmann, DVM and João Francisco Nunes.

\section{REFERENCES}

1. Ludwin SK. The function of the perineuronal satellite oligodendrocyte: an immunohistochemical study. Neuropath Appl Neurobiol 1984;10; 143-149.

2. Woodruff RH, Franklin RJM. Demyelination and remyelination of the caudal cerebellar peduncle of adult rats following stereotaxic injections of lysolecithin, ethidium bromide, and complement/ anti-galactocerebroside: a comparative study. Glia 1999;25:216-228.

3. Graça DL, Blakemore WF. Delayed remyelination of rat spinal cord following ethidium bromide injection. Neuropath Appl Neurobiol 1986;12: 593-608.

4. Fernandes CG, Pereira LAV, Graça DL. Inflammatory response of the spinal cord to multiple episodes of blood-brain barrier disruption and toxic demyelination in Wistar rats. Braz J Med Biol Res 1998; 31: 933-936. 
5. Pereira LAV, Dertkigil MSJ, Graça DL, Cruz-Höfling MA. Dynamics of remyelination in adult rat brain after exposure to ethidium bromide. J Submicr Cytol Pathol 1998;30:297-301.

6. Bondan EF, Lallo MA, Sinhorini IL, Pereira LAV, Graça DL. The effect of cyclophosphamide on brainstem remyelination following local ethidium bromide injection in Wistar rats. J Submicr Cytol Pathol 2000;32: 431-438.

7. Riet-Correa G, Fernandes CG, Pereira LAV, Graça DL. Ethidium bromide-induced demyelination of the sciatic nerve of adult Wistar rats. Braz J Med Biol Res 2002;35:99-104.

8. Bondan EF, Lallo MA, Graça DL. Efeitos do brometo de etídio no tronco encefálico de ratos Wistar imunossuprimidos com ciclosporina. Cad Est Pesq UNIP 1998;IV:1-46.

9. B ronstein JM, Popper P, Micevych PE, Farber DB. Isolation and characterization of a novel oligodendrocyte-specific protein. Neurology 1996;47:772-778.

10. B ronstein JM, Micevych PE, Cehn K. Oligodendrocyte-specific protein (OSP) is a major component of CNS myelin. J Neurosci Res 1997;50: 713-720.

11. Sims TJ, Gilmore SA, Waxman SG, Klinge E. Dorsal-ventral differences in the glia limitans of the spinal cord: an ultrastructural study in developing and irradiated rats. J Neuropathol Exp Neurol 1985;44:415-429.

12. Franklin RJ, Blakemore WF. Requirements for Schwann cells migration within CNS environments: a viewpoint. Int J Dev Neurosci 1993;11: 641-649.
13. Graça DL, Bondan EF, Pereira LAV, Fernandes CG, Maiorka PC. Behaviour of oligodendrocytes and Schwann cells in an experimental model of toxic demyelination of the central nervous system. Arq Neuropsiquiatr 2001;59:358-361.

14. Shigeko F, Shirabe T. The reaction of glial progenitor cells in remyelination following ethidium bromide-induced demyelination in the mouse spinal cord. Neuropathology 2002;22:233-242.

15. Levine JM, Reynolds, R. Activation and proliferation of endogenous oligodendrocyte precursor cells during ethidium bromide-induced demyelination. Exp Neurol 1999;160:333-347.

16. Tiwari-Woodruff SK, Buznikov AG, Vu TQ, et al. OSP/Claudin-11 forms a complex with a novel member of the tetraspanin super family and $\beta 1$ integrin and regulates proliferation and migration of oligodendrocytes. J Cell Biol 2005;153:295-305.

17. Pereira LAV, Crua-Höfling MA, Dertkigil MSJ, Graça DL. Biology of the repair of central nervous system demyelinated lesions. Arq Neuropsiquiatr 1996;54:331-334.

18. Noble M, Ataliotis P, Barnett SC, et al. Development, regeneration and neoplasia of glial cells in the central nervous system. An NY Acad Sci 1991;633:35-47.

19. Chang A, Nishiyama A, Peterson J, Prineas J, Trapp BD. NG2 positive oligodendroyte progenitor cells in adult human brain and multiple sclerosis lesions. J Neurosci 2000;20:6404-6412.

20. Franklin RJM. Why does remyelination fail in multiple sclerosis? Nature Rev Neurosci 2002;3:705-771. 